\title{
Control of the lipid oxidation in Nile tilapia feed
}

\author{
Controle da oxidação lipídica em ração para tilápia do Nilo
}

\author{
Thiago Luís Magnani Grassi ${ }^{i^{*}}$ Marcelo Tacconi de Siqueira $\operatorname{Marcos}^{\mathrm{I}}$ \\ Elisa Helena Giglio Ponsano ${ }^{\mathrm{I}}$
}

\begin{abstract}
The purpose of this research was to investigate the progress of the rancidity in Nile tilapia diets containing bacterial biomass of Rubrivivax gelatinosus. Six experimental treatments comprised basal diet (negative control), diet with asthaxanthin (positive control) and 4 diets with different concentrations of the bacterial biomass. The thiobarbituric acid assay for rancidity analyses were accomplished after 6 and 12 months of diets storage. It was concluded that Rubrivivax gelatinosus biomass minimized the racidity in Nile tilapia diets in 32.52 to $44.72 \%$ at 6 months and in 37.85 to $52.37 \%$ at 12 months of storage.
\end{abstract}

- NOTE
Key words: Antioxidant, rancidity, Rubrivivax gelatinosus, TBARS

\section{RESUMO}

O objetivo deste trabalho foi avaliar o curso da rancidez oxidativa em rações de tilápia do Nilo contendo biomassa bacteriana de Rubrivivax gelatinosus. Foram aplicados seis tratamentos experimentais constituídos de ração basal (controle negativo), ração basal contendo astaxantina (controle positivo) $e$ ração basal contendo quatro concentrações da biomassa bacteriana. As análises de ácido tiobarbitúrico para estimar a rancidez foram realizadas após 6 e 12 meses de armazenamento das rações. Concluiu-se que a biomassa de $\boldsymbol{R}$. gelatinosus foi capaz de reduzir a rancidez da ração de peixes em 32,52 a 44,72\% após 6 meses de armazenamento e em 37,85 a 52,37\% após 12 meses de estocagem.

Palavras-chave: Antioxidante, rancidez, Rubrivivax gelatinosus, TBARS

According to BORGHESI et al. (2013), utilization of oils and fats for animal feeding has increased in the last years due to the multiple benefits that these ingredients may provided to the animal performance. More than energy source, the dietary lipids play an important role in physiological processes and influence the body fatty acids, thus acting directly on animals' growth, meat yield and fillets quality (JUSTI et al., 2003).

However, the unsaturated fatty acids of the feed may undergo oxidative rancidity, an oxygen-dependent deterioration process mediated by light, heat and metals, which follows the formation of undesirable sensory compounds. Therefore, the ration may get unpalatable and toxic due to aldehydes, ketones, esters, hydrocarbons and other compounds, so becoming a potential hazard for the animals (ORDÓÑEZ, 2005).

Although synthetic antioxidants have widely been used in animal feeding to prevent rancidity, currently, they became an objection subject regarding their harmlessness (ANESINI et al., 2006), so rising the concern of the industry towards the search for alternative natural antioxidants.

In such context, some carotenoids are referred to hold relevant antioxidant properties in foods and feeds, more than just a pigmenting ability, so minimizing the lipids deterioration (BHOSALE \& BERNSTEIN, 2005). Moreover, some carotenoids may act against oxidative stress by combating the free radicals and increasing the immune response, thus fomenting the animals' growth and welfare (SHINDO et al., 2007).

\footnotetext{
'Departamento de Apoio, Produção e Saúde Animal, Faculdade de Medicina Veterinária (FMVA), Universidade Estadual Paulista "Júlio de Mesquita Filho" (UNESP), Campus de Araçatuba, Rua Clóvis Pestana, 793, 16050-680, Araçatuba, SP, Brasil. E-mail: thiagograssi@fmva.unesp.br. "Corresponding author. 
Some examples of carotenoids with antioxidant properties are asthaxanthin and the bacterial oxycarotenoids produced by Rubrivivax gelatinosus. The bacterium grows in industry effluents consuming their organic load and producing a biomass containing mainly protein and oxycarotenoids (HIGUERA-CIAPARA et al., 2006; PONSANO et al., 2011). The aim of this study was to evaluate the effect of the Rubrivivax gelatinosus biomass on the course of the lipid oxidation of feeds made for Nile tilapia.

It was used a completely randomized design with six treatments and three repetitions. The basal diet was formulated according to FURUYA et al. (2010) recommendations for tilapia (Table 1) and extruded. It contained $30.52 \%$ protein, $6.42 \%$ lipids and $7.99 \%$ minerals. Treatments comprised the basal diet without antioxidants (negative control), the basal diet added of $350 \mathrm{mg} \mathrm{kg}^{-1}$ Carophyll pink (asthaxanthin 10\%, DSM, positive control) and the basal diet added of 175, 350, 700 and $1400 \mathrm{mg}$ $\mathrm{kg}^{-1}$ Rubrivivax gelatinosus biomass $\left(3 \mathrm{mg} \mathrm{g}^{-1}\right.$ carotenoids and $60 \%$ proteins). These products were mixed to the basal diet inside a Y mixer after their previous dissolution in soy oil and the same amount of soy oil was added to the control group. Experimental diets were stored in the dark inside plastic bags (polypropylene) at room temperature $\left(25^{\circ} \mathrm{C}\right)$ for 12 months.

The lipid oxidation was essayed with the TBARS methodology according to AVANÇO (2012) after 6 and 12 months of storage. The results were analyzed by ANOVA and the means were compared by Tukey's test at $5 \%$ significance.

After 6 months of storage (Table 2), except the treatment with the asthaxanthin, all the other treatments had TBARS values lower than the control group ( $\mathrm{P}=0.0058)$; although, not significantly. But, after 12 months of storage, all treatments containing the antioxidant products had significantly lower rancidity than the negative control group (Table 2). Treatments containing the highest biomass concentrations (700 and $1400 \mathrm{mg} \mathrm{kg}^{-1}$ ) were the most effective to minimize the rancidity. Compared to the negative control group, the treatments containing the bacterial biomass reduced the TBARS values in 32.52 to $44.72 \%$ and in 37.85 to $52.37 \%$ at 6 and 12 months of storage, respectively.

Table 1 - Experimental diets for Nile tilapia.

\begin{tabular}{|c|c|c|c|c|c|c|}
\hline \multirow[b]{2}{*}{ Ingredients } & \multirow[b]{2}{*}{$\begin{array}{c}\text { Negative } \\
\text { control }\end{array}$} & \multirow[b]{2}{*}{$\begin{array}{l}\text { Positive } \\
\text { control }\end{array}$} & \multirow[b]{2}{*}{$\begin{array}{c}\text { Bacterial } \\
\text { biomass } 175 \mathrm{mg} \\
\mathrm{kg}^{-1}\end{array}$} & \multirow[b]{2}{*}{$\begin{array}{c}\text { Bacterial } \\
\text { biomass } 350 \mathrm{mg} \\
\mathrm{kg}^{-1}\end{array}$} & \multirow[b]{2}{*}{$\begin{array}{c}\text { Bacterial } \\
\text { biomass } 700 \mathrm{mg} \mathrm{b} \\
\mathrm{kg}^{-1}\end{array}$} & \multirow[b]{2}{*}{$\begin{array}{c}\text { Bacterial } \\
\text { biomass } 1400 \mathrm{mg} \\
\mathrm{kg}^{-1} \\
\end{array}$} \\
\hline & & & & & & \\
\hline Ground corn (\%) & 6.42 & 6.42 & 6.42 & 6.42 & 6.42 & 6.42 \\
\hline Poultry meal by-products (\%) & 8 & 8 & 8 & 8 & 8 & 8 \\
\hline Soybean meal (\%) & 45 & 45 & 45 & 45 & 45 & 45 \\
\hline Wheat meal (\%) & 17 & 17 & 17 & 17 & 17 & 17 \\
\hline Broken rice $(\%)$ & 7.6 & 7.6 & 7.6 & 7.6 & 7.6 & 7.6 \\
\hline Whole rice meal (\%) & 5 & 5 & 5 & 5 & 5 & 5 \\
\hline Meat meal (\%) & 6 & 6 & 6 & 6 & 6 & 6 \\
\hline Binder $(\%)$ & 0.1 & 0.1 & 0.1 & 0.1 & 0.1 & 0.1 \\
\hline Salt $(\%)$ & 0.3 & 0.3 & 0.3 & 0.3 & 0.3 & 0.3 \\
\hline Dicalcium phosphate (\%) & 1.32 & 1.32 & 1.32 & 1.32 & 1.32 & 1.32 \\
\hline Soybean oil (\%) & 2.13 & 2.13 & 2.13 & 2.13 & 2.13 & 2.13 \\
\hline Choline chloride $70 \%(\%)$ & 0.2 & 0.2 & 0.2 & 0.2 & 0.2 & 0.2 \\
\hline DL-Methionine (\%) & 0.22 & 0.22 & 0.22 & 0.22 & 0.22 & 0.22 \\
\hline Antifungal (Fylax) (\%) & 0.2 & 0.2 & 0.2 & 0.2 & 0.2 & 0.2 \\
\hline Mineral and vitamin $\operatorname{mix}^{1(\%)}$ & 0.5 & 0.5 & 0.5 & 0.5 & 0.5 & 0.5 \\
\hline Carophyll Pink (Astaxanthin 10\%) (mg/kg) & 0 & 350 & 0 & 0 & 0 & 0 \\
\hline R. gelatinosus biomass $\left(\mathrm{mg} \mathrm{kg}^{-1}\right)$ & 0 & 0 & 175 & 350 & 700 & 1400 \\
\hline
\end{tabular}

${ }^{1}$ Composition per kg of the product: Vit. A 2400000 UI; Vit. D3 600000 UI; Vit. E 30000 mg; Vit. K3 3000 mg; Vit. B1 4000 mg; Vit. B2 4000 mg; Vit. B6 3500 mg; Vit. B12 8000 mg; Vit. C 60000 mg; Nicotinic acid 20000 mg; Pantothenic calcium 10000 mg; Biotin 200 mg; Folic acid 1200 mg; Cu 3500 mg; Fe 20000 mg; Mn 10000 mg; Zn 24000 mg; Ca 160 mg; Na 100 mg; Co 80 mg; Inositol 25000 mg; Choline chloride $100000 \mathrm{mg}$. 
Table 2 - Lipid oxidation of Nile tilapia feed.

\begin{tabular}{lcc}
\hline \multirow{2}{*}{ Treatment } & \multicolumn{2}{c}{ TBARS (mg de malonaldeid $\mathrm{kg}^{-1}$ ) } \\
& 6 months & 12 months \\
\hline Negative control & $2.46 \pm 0.45^{\mathrm{a}}$ & $3.17 \pm 0.18^{\mathrm{a}}$ \\
Positive control & $2.01 \pm 0.34^{\mathrm{ab}}$ & $2.17 \pm 0.18^{\mathrm{b}}$ \\
Bacterial biomass $175 \mathrm{mg} \mathrm{kg}$ & $1.57 \pm 0.17^{\mathrm{b}}$ & $1.97 \pm 0.09^{\mathrm{bc}}$ \\
Bacterial biomass $350 \mathrm{mg} / \mathrm{kg}^{-1}$ & $1.66 \pm 0.23^{\mathrm{b}}$ & $1.83 \pm 0.18^{\mathrm{bc}}$ \\
Bacterial biomass $700 \mathrm{mg} \mathrm{kg}$ & $1.55 \pm 0.15^{\mathrm{b}}$ & $1.61 \pm 0.24^{\mathrm{c}}$ \\
Bacterial biomass $1400 \mathrm{mg} \mathrm{kg}^{-1}$ & $1.36 \pm 0.28^{\mathrm{b}}$ & $1.51 \pm 0.12^{\mathrm{c}}$ \\
$\mathrm{P}$ & 0.0058 & $<0.0001$ \\
\hline
\end{tabular}

${ }^{\mathrm{a}, \mathrm{b}}$ Means followed by different letters are significantly different $(\mathrm{P}<0.05)$.

So, it was demonstrated that the carotenoids tested were efficient to reduce the lipid oxidation in the tilapia diet, so providing a longer preservation of the sensory properties. Taking into account the researches regarding the toxic effects, the synthetic antioxidants may bring to health (PONCE-PALAFOX et al., 2004) and on the basis of the results found in this study, we presume that the Rubrivivax gelatinosus biomass may be used as a natural antioxidant for those rations.

GRASSI et al. (2016) had already reported an increase in the proteins content of the fillets of tilapias fed with bacterial biomass, as well as an increase in the concentration of carotenoids and a desirable fatty acids composition and SANTO et al. (2016) confirmed the antioxidant activity of the biomass on the fish fillets. However, this was the first time the product was used to prevent rancidity in animal diets and the results indicated its probable practical application.

It was concluded that Rubrivivax gelatinosus biomass minimized the racidity in Nile tilapia diets until 12 months of storage.

\section{REFERENCES}

ANESINI, C. et al. Peroxidase-like activity of Ilex paraguariensis. Food Chemistry, v.97, n.3, p.459-464, 2006. Available from: $<$ http://www.sciencedirect.com/science/article/pii/ S0308814605004000>. Accessed: Jan. 10, 2015. doi: 10.1016/j. foodchem.2005.05.025.

AVANÇO, S. V. Use of Rubrivivax gelatinosus biomass into broilers chicken feed: animal performance and products attributes. 71f. Dissertação (Mestrado em Ciência Animal) Faculdade de Medicina Veterinária, Universidade Estadual Paulista, Araçatuba.
BHOSALE, P.; BERNSTEIN, P.S. Microbial xanthophylls. Applied Microbiology and Biotechnology, v.68, n.4, p.445-455, 2005. Available from: <http://dx.doi. org/10.1007/s00253-005-0032-8>. Accessed: Jan. 2015. doi: $10.1007 / \mathrm{s} 00253-005-0032-8$.

BORGHESI, R. et al. Influência da nutrição sobre a qualidade do pescado: especial referência aos ácidos graxos. Corumbá: Embrapa Pantanal - MAPA, 2013. Available from: $<$ http://ainfo cnptia.embrapa.br/digital/bitstream/item/101699/1/DOC124.pdf $>$. Accessed: Sept. 23, 2015

FURUYA, W.M. et al. Tabelas brasileiras para a nutrição de tilápias. Toledo: GFM, 2010. 100 p.

GRASSI, T.L.M. et al. Bacterial pigment for Nile tilapia feeding. Aquaculture International, v.24, n.2, p.647660, 2016. Available from: <http://link.springer.com/ article/10.1007/s10499-015-9955-y>. Accessed: Feb. 01, 2016. doi: 10.1007/s10499-015-9955-y.

HIGUERA-CIAPARA, I. et al. Astaxanthin: a review of its chemistry and applications. Critical Reviews in Food Science and Nutrition, v.46, n.2, p.185-196, 2006. Available from: $<$ http://www.tandfonline.com/doi/pdf/10.1080/104086905909571 88>. Accessed: Jan. 10, 2015. doi: 10.1080/10408690590957188.

JUSTI, K.C. et al. The influence of feed supply time on the fatty acid profile of Nile tilapia (Oreochromis niloticus) fed on a diet enriched with n-3 fatty acids. Food Chemistry, v.80, n.4, p.489493, 2003. Available from: <http://www.sciencedirect.com/ science/article/pii/S0308814602003175>. Accessed: Jan. 10, 2015. doi: 10.1016/S0308-8146(02)00317-5.

ORDÓÑEZ, J.A. Tecnologia de alimentos. 2.ed. Porto Alegre: Artmed, 2005. 279p.

PONSANO, E.H.G. et al. From a pollutant byproduct to a feed ingredient. In: MANTOVIC, D. Biomass: detection, production and usage. Rijeka: Intech, 2011. p.461-472.

PONCE-PALAFOX, J.T. et al. Pigmentación de la tilapia (Oreochromis niloticus) con carotenoides de flor de cempasúchil (Tagetes erecta) en comparación con la astaxantina. Revista Mexicana de Ingeniería Química, v.3, n.2, p.219-225, 2004. Available from: <http://www.redalyc.org/articulo. oa?id=62030207>. Accessed: Mar. 10, 2016.

SANTO, E.F.E. et al. Performance, animal health and fillets quality fed diets supplemented with bacterial biomass. Arquivo Brasileiro de Medicina Veterinária e Zootecnia, v.68, n.2, p.525-534, 2016 Available from: $<$ http://cpro4576.publiccloud.com.br:8080/editora// upload/trabalho/10576-22718.pdf>. Accessed: Mar. 10, 2016.

SHINDO, K. et al. Rare carotenoids, (3R)-saproxanthin and $(3 R, 2$ 'S)-myxol, isolated from novel marine bacteria (Flavobacteriaceae) and their antioxidative activities. Applied Microbiology and Biotechnology, v.74, n.6, p.13501357, 2007. Available from: <http://link.springer.com/ article/10.1007\%2Fs00253-006-0774-y>. Accessed: Jan. 10, 2015. doi: 10.1007/s00253-006-0774-y. 